\title{
Pengaruh Pengencer Kuning Telur dengan Air Kelapa dan Lama Penyimpanan terhadap Kualitas Semen Kambing Nubian
}

\author{
The Effect of Egg Yolk with Coconut Water Diluter and Storage Time on Nubian Goat semen \\ Dwatmadji $^{1}$, Siwitri Kadarsih ${ }^{1}$, Edi Sutrisno ${ }^{1}$, Yanti Fisniarsih ${ }^{2}$ \\ ${ }^{1}$ Staf Pengajar Jurusan Peternakan Fakultas Pertanian Universitas Bengkulu \\ Jalan Raya Kandang Limun Bengkulu Telp. (0736) 21170 Pst 219. \\ ${ }^{2}$ Mahasiswa Jurusan Peternakan Fakultas Pertanian Universitas Bengkulu
}

\begin{abstract}
The purpose of this research was to evaluate the effect of egg yolk with coconut water diluter and storage length to Nubian goat semen quality. Two Nubian Bucks, approximately \pm 6 years of age were used in this research. After collection, the semen was diluted with combination of egg yolk and coconut water (P1 = $100 \%$ egg yolk, $\mathrm{P} 2=75 \%$ egg yolk $+25 \%$ coconut water, $\mathrm{P} 3=50 \%$ egg yolk $+50 \%$ coconut water, $\mathrm{P} 4=25 \%$ egg yolk $+75 \%$ coconut water, $\mathrm{P} 5=100 \%$ coconut water), then stored to evaluated the quality of semen in macroscopic and microscopic after 2 days storage, 4 days storage, 6 days storage, and 8 days storage. The result of this research showed that Nubian goat semen can be diluted. The good diluter is $75 \%$ egg yolk with $25 \%$ coconut water and $50 \%$ egg yolk with $50 \%$ coconut water, and the good storage is two days storage.
\end{abstract}

Key words: Nubian Buck, extender, storage, semen quality

\section{ABSTRAK}

Penelitian ini bertujuan untuk mengevaluasi pengaruh pengencer kuning telur dengan air kelapa dan lama penyimpanan terhadap kualitas semen kambing Nubian. Kambing Nubian yang digunakan berjumlah dua ekor berumur \pm 6 tahun. Semen hasil koleksi diencerkan menggunakan berbagai level pengencer kuning telur dengan air kelapa ( $\mathrm{P} 1=100 \%$ kuning telur, $\mathrm{P} 2=75 \%$ kuning telur $+25 \%$ air kelapa, $\mathrm{P} 3=50 \%$ kuning telur $+50 \%$ air kelapa, P4=25\% kuning telur + 75\% air kelapa, P5=100\% air kelapa), lalu disimpan untuk diuji kualitasnya baik secara makroskopik maupun mikroskopik pada saat lama penyimpanan 2 hari, 4 hari, 6 hari, dan 8 hari. Hasil penelitian menunjukkan bahwa semen kambing Nubian memenuhi syarat untuk diencerkan. Pengencer yang dapat mempertahankan kualitas semen kambing Nubian adalah pengencer $75 \%$ kuning telur dengan $25 \%$ air kelapa dan pengencer $50 \%$ kuning telur dengan $50 \%$ air kelapa, dan saat penyimpanan yang paling baik adalah selama dua hari.

Kata kunci : kambing Nubian, pengencer, penyimpanan, kualitas semen

\section{PENDAHULUAN}

Inseminasi buatan merupakan salah satu cara untuk meningkatkan populasi dan produksi ternak secara kualitatif maupun kuantitatif dengan menggunakan semen pejantan yang bebas penyakit dan mempunyai mutu genetik tinggi. Menurut Toelihere (1981), semen yang tidak diencerkan dan dibiarkan pada suhu $28-34^{\circ} \mathrm{C}$ hanya bertahan selama dua jam, tetapi apabila disimpan pada suhu $37-38^{\circ} \mathrm{C}$ dapat bertahan sampai tiga jam (Haenlein et al., 2007).
Lingkungan merupakan sumber kontaminan bagi spermatozoa, semen dapat terkontaminasi oleh lebih dari 13 jenis bakteri yang dapat berasal dari ternak (feses, praeputium, dan kulit) atau dari luar ternak seperti lantai dan area laboratorium (Poolperm, 2001).

Untuk mempertahankan kualitas sperma, semen yang telah dikoleksi dapat di preservasi dengan cara diencerkan kemudian disimpan pada kondisi yang bertemperatur rendah. Penyimpanan semen pada temperatur rendah dapat merusak sperma. Kerusakan sperma karena cold shock dapat dikurangi dengan menggunakan pengencer yang 
mengandung lechitin dan lipoprotein (Toelihere, 1981).

Menurut Toelihere (1981), syarat pengencer yang digunakan adalah murah, sederhana dan praktis dibuat, mengandung unsur-unsur yang hampir sama sifat fisik dan kimiawi dengan semen, tidak mengandung zat racun baik terhadap sperma maupun saluran kelamin betina, tetap mempertahankan dan tidak membatasi daya fertilisasi sperma, dan memungkinkan dilakukannya penilaian sperma setelah pengenceran. Bahan pengencer yang ada saat ini tidak dapat memenuhi semua syarat tersebut sehingga diperlukan kombinasi antara bahan pengencer seperti susu, kuning

telur, dan air kelapa

Air kelapa merupakan bahan yang dapat digunakan sebagai pengencer semen. Air kelapa mengandung karbohidrat 4,11\%-7,27\% (Afiati dkk., 2003), bahan kering $(50,0 \%)$, protein kasar $(7,4 \%)$, serat kasar $(3,0 \%)$, abu $(2,0 \%)$, ekstrak eter $(68,0 \%)$, kalsium (0,03\%), dan phosphor (0,26\%) (FAO, 1998).

Air kelapa tidak mampu melindung spermatozoa dari temperatur rendah, oleh karena itu perlu ditambah kuning telur atau zat lain. Kuning telur dapat melindungi spermatozoa dari cold shock karena mengandung lipoprotein dan lechitin (Toelihere, 1981). Kuning telur mengandung glukosa yang lebih efektif digunakan oleh spermatozoa, protein, dan memiliki viskositas yang menguntungkan bagi spermatozoa

(Toelihere, 1981; Yuliyanti, 2001), Pengaruh pengencer kuning telur dengan air kelapa terhadap kualitas semen kambing Nubian belum pernah dilaporkan, oleh karena itu mendorong untuk dilakukan penelitian ini.

\section{MATERI DAN METODE}

Penelitian ini dilaksanakan tanggal 1 - 31 Juli 2007 di Lembaga Pengembangan Pertanian Baptis Taman Hutan Raya Bengkulu. Bahan yang digunakan pada penelitian ini adalah semen kambing Nubian jantan sebanyak 2 ekor umur \pm 6 tahun, air kelapa hijau muda, kuning telur itik, $\mathrm{NaCl}$ 0,3\%, antibiotik penisilin streptomisin (Meiji), pewarna eosin $10 \%$, spiritus, lubricant (Durex) dan alkohol $70 \%$. Alat yang digunakan adalah vagina buatan kambing (Minitub), mikroskop cahaya, haemocytometer improved Neubaueri, kertas $\mathrm{pH}$ indikator skala 5-10 (Merck), dan lemari es.
Penelitian ini menggunakan rancangan percobaan Rancangan Acak Lengkap (RAL) yang disusun secara faktorial dengan dua faktor. Faktor pertama adalah berbagai level pengencer kuning telur dengan air kelapa $(P)$ yang terdiri dari $100 \%$ kuning telur, $75 \%$ kuning telur $+25 \%$ air kelapa, $50 \%$ kuning telur $+50 \%$ air kelapa, $25 \%$ kuning telur + 75\% air kelapa, dan $100 \%$ air kelapa. Faktor kedua adalah lama penyimpanan semen dalam lemari es (W) yang terdiri dari Penyimpanan 2 hari, 4 hari, 6 hari, dan 8 hari.

Koleksi semen dilakukan dengan menggunakan vagina buatan setiap tiga hari sekali pada pagi hari. Semen segar yang dikoleksi diuji kualitasnya secara makroskopik $(\mathrm{pH}$, volume, dan warna) dan mikroskopik yang meliputi konsentrasi, motilitas, persentase sperma hidup, dan persentase abnormalitas sperma, dan yang memiliki kriteria persentase sperma hidup $>40 \%$, motilitas sedang, dan persentase abnormalitas $<20 \%$ diencerkan menggunakan kuning telur itik dengan air kelapa (Hafez, 2000; Anonimous, 2002). Semen yang telah diencerkan disimpan di dalam lemari es dengan suhu $4-7^{\circ} \mathrm{C}$, dan dievaluasi secara makroskopik $(\mathrm{pH})$ dan mikroskopik (motilitas, persentase sperma hidup, dan persentase abnormalitas spermatozoa) saat waktu penyimpanan 2, 4, 6, dan 8 hari.

Data yang didapat ditabulasi dan dianalisis anova mengunakan sofware SPSS for windows ver. 11.0, jika terdapat perbedaan yang nyata maka akan diuji lebih lanjut dengan DMRT (Steel dan Torrie, 1993).

\section{HASIL DAN PEMBAHASAN}

Hasil uji makroskopik dan mikroskopik semen segar dapat dilihat pada Tabel 1. di bawah ini.

Hasil uji makroskopik dan mikroskopik semen segar (Tabel 1.) menunjukkan bahwa semen kambing Nubian mempunyai kualitas yang baik dan normal, serta memenuhi persyaratan untuk diencerkan yaitu motilitas massa minimal skor +2 , konsentrasi spermatozoa minimal $1000 \times 10^{6} / \mathrm{ml}$, persentase abnormalitas spermatozoa maksimal $15 \%$, dan persentase sperma hidup minimal $70 \%$ (Anonimous, 2001). Volume semen kambing Nubian dalam penelitian ini sebanyak $1+0,00 \mathrm{ml}$ dengan konsentrasi spermatozoa 2485 $\$ 106,07$ juta/ml, warna krem dengan konsistensi kental, dan $\mathrm{pH}$ semen $6,50 \pm 0,50$ berada pada kisaran normal (Haenlein et al., 2007 ; Jiabi et al., 2001; Garner and Hafez, 2000). 
Tabel 1. Data rata-rata hasil pengamatan uji makroskopik dan mikroskopik semen segar kambing Nubian

\begin{tabular}{lc}
\hline \multicolumn{1}{c}{ Variabel pengamatan } & Semen segar \\
\hline Volume semen $(\mathrm{ml})$ & $1 \pm 0,00$ \\
Warna & krem \\
Derajat keasaman $(\mathrm{pH})$ & $6,50 \pm 0,50$ \\
Konsistensi & kental \\
Motilitas massa (skor) & $3,00 \pm 0,00$ \\
Motilitas individu (skor) & $3,00 \pm 0,00$ \\
Konsentrasi spermatozoa (juta/ml) & $2485 \pm 106,07$ \\
Spermatozoa hidup (\% H) & $80,54 \pm 1,69$ \\
Abnormalitas spermatozoa $(\% \mathrm{AB})$ & $12,80 \pm 0,79$ \\
\hline
\end{tabular}

Pengaruh pengencer dan lama

Tabel 2 di bawah ini.

penyimpanan terhadap $\mathrm{pH}$ semen dapat dilihat di

Tabel 2. Rata-rata pH semen

\begin{tabular}{|c|c|c|c|c|c|c|}
\hline \multirow{2}{*}{ Waktu Penyimpanan } & \multicolumn{6}{|c|}{ Pengencer } \\
\hline & P1 & P2 & P3 & P4 & P5 & Rataan \\
\hline 2 hari (W1) & $5,93 \pm 0,12$ & $6,00 \pm 0,00$ & $6,00 \pm 0,00$ & $5,83 \pm 0,29$ & $5,70 \pm 0,17$ & $5,89+0,18^{a}$ \\
\hline 4 hari (W2) & $5,87 \pm 0,12$ & $5,93 \pm 0,12$ & $6,00 \pm 0,00$ & $5,67 \pm 0,29$ & $5,50 \pm 0,00$ & $5,79 \pm 0,23^{a}$ \\
\hline 6 hari (W3) & $5,67 \pm 0,29$ & $5,77 \pm 0,25$ & $5,87 \pm 0,12$ & $5,50 \pm 0,00$ & $5,50 \pm 0,00$ & $5,66 \pm 0,21^{b}$ \\
\hline 8 hari (W4) & $5,50 \pm 0,00$ & $5,50 \pm 0,00$ & $5,77 \pm 0,25$ & $5,50 \pm 0,00$ & $5,33 \pm 0,29$ & $5,52 \pm 0,20^{c}$ \\
\hline Rataan & $5,74 \pm 0,23^{b c}$ & $5,80 \pm 0,23^{a b}$ & $5,91 \pm 0,16^{a}$ & $5,63 \pm 0,23^{c d}$ & $5,51 \pm 0,20^{d}$ & \\
\hline
\end{tabular}

Keterangan : Superskrip yang sama pada kolom dan baris yang sama menunjukkan berbeda tidak nyata $(P>0,05)$., ns= Berbeda tidak nyata ( $\mathrm{P}>0,05), \mathrm{P} 1:$ 100\% kuning telur, P2: 75\% kuning telur dengan 25\% air kelapa, P3: 50\% kuning telur dengan 50\% air kelapa, P4: 25\% kuning telur dengan 75\% air kelapa, P5: 100\% air kelapa.

Hasil analisis ragam menunjukkan tidak terdapat interaksi $(P>0,05)$ antara pengencer dengan waktu penyimpanan terhadap $\mathrm{pH}$ semen. Walaupun berbeda tidak nyata $(\mathrm{P}>0,05)$, diketahui bahwa pada perlakuan P2 dan P3 dapat mempertahankan pH normal semen sampai hari ke empat, tetapi P1 hanya dapat mempertahankan $\mathrm{pH}$ semen sampai hari ke dua penyimpanan, bahkan pada P4 dengan $\mathrm{pH}$ semen $5,83 \pm 0,29$ dan $\mathrm{P} 5$ dengan $\mathrm{pH}$ semen 5,70 $\pm 0,17$ pada hari ke dua sudah tidak normal lagi.

Hasil analisis ragam menunjukkan bahwa pengencer berpengaruh sangat nyata $(P<0,01)$ terhadap $\mathrm{pH}$ semen. Dari Tabel 2. diketahui bahwa rataan $\mathrm{pH}$ semen yang tertinggi terdapat pada perlakuan P3. Uji lanjut yang dilakukan menunjukkan bahwa rataan $\mathrm{pH}$ semen pada $\mathrm{P} 3$ berbeda tidak nyata $(\mathrm{P}<0,05)$ dengan rataan $\mathrm{pH}$ semen pada perlakuan $\mathrm{P} 2$, walaupun berbeda tidak nyata $(P<0,05)$ rataan $\mathrm{pH}$ semen pada perlakuan $\mathrm{P3}$ masih berada pada kisaran normal yaitu 5,91+0,16. Secara keseluruhan $\mathrm{pH}$ semen mengalami penurunan. Penurunan $\mathrm{pH}$ ini diduga disebabkan karena pengaruh $\mathrm{pH}$ pengencer. Salisburry dan Vandemark (1985) menyatakan bahwa salah satu faktor yang mempengaruhi $\mathrm{pH}$ semen yang telah diencerkan adalah $\mathrm{pH}$ pengencer.

Data pada Tabel 2. menunjukkan bahwa semakin lama waktu penyimpanan maka $\mathrm{pH}$ semen yang diencerkan mengalami penurunan. Rataan $\mathrm{pH}$ semen tertinggi terdapat pada penyimpanan selama dua hari. Analisis ragam menunjukkan bahwa lama penyimpanan berpengaruh sangat nyata $(P<0,01)$ terhadap $\mathrm{pH}$ semen. Uji lanjut memperlihatkan bahwa rataan $\mathrm{pH}$ semen pada saat lama penyimpanan 2 hari $(5,89 \pm 0,18)$ berbeda tidak nyata $(\mathrm{P}>0,05)$ dengan rataan $\mathrm{pH}$ semen pada saat lama penyimpanan empat hari $(5,79 \pm 0,23)$. Menurut Toelihere (1981), penambahan waktu penyimpanan menyebabkan penurunan derajat keasaman $(\mathrm{pH})$ 
semen. Junianto dkk. (2002) dan Yani et al. (2001) menjelaskan bahwa penurunan $\mathrm{pH}$ semen disebabkan oleh metabolisme anaerobik atau proses glikolisis spermatozoa secara alamiah yang menghasilkan asam laktat.
Motilitas spermatozoa mengalami penurunan, hasil pengamatan motilitas massa dan individu sperma dapat dilihat pada Tabel 3.

Tabel 3. Rata-rata motilitas massa dan individu sperma

\begin{tabular}{|c|c|c|c|c|c|c|}
\hline \multirow{2}{*}{$\begin{array}{c}\text { Waktu } \\
\text { Penyimpanan }\end{array}$} & \multirow{2}{*}{$\begin{array}{c}\text { Variabel } \\
\text { Pengamatan }\end{array}$} & \multicolumn{5}{|c|}{ Pengencer } \\
\hline & & $\mathrm{P} 1$ & $\mathrm{P} 2$ & P3 & P4 & P5 \\
\hline \multirow[t]{2}{*}{2 hari (W1) } & motilitas massa & $3,00 \pm 0,00^{a}$ & $3,00 \pm 0,00^{a}$ & $3,00 \pm 0,00^{a}$ & $2,67 \pm 0,58^{a}$ & $1,33 \pm 0,58^{b c}$ \\
\hline & motilitas individu & $3,00 \pm 0,00^{a}$ & $3,00 \pm 0,00^{a}$ & $3,00 \pm 0,00^{a}$ & $2,67 \pm 0,58^{a}$ & $1,67 \pm 0,58^{b}$ \\
\hline \multirow[t]{2}{*}{4 hari (W2) } & motilitas massa & $1,00 \pm 0,00^{c d}$ & $1,67 \pm 0,58^{b}$ & $1,00 \pm 0,00^{c d}$ & $1,00 \pm 0,00^{c d}$ & $0,67 \pm 0,58^{\text {de }}$ \\
\hline & motilitas individu & $1,00 \pm 0,00^{c}$ & $1,67 \pm 0,58^{b}$ & $1,67 \pm 0,58^{b}$ & $1,00 \pm 0,00^{c}$ & $0,67 \pm 0,58^{c}$ \\
\hline \multirow[t]{2}{*}{6 hari (W3) } & motilitas massa & $0,33 \pm 0,58^{\mathrm{ef}}$ & $0,67 \pm 0,58^{\mathrm{de}}$ & $0,33 \pm 0,58^{\mathrm{ef}}$ & $0,00 \pm 0,00^{f}$ & $0,00 \pm 0,00^{f}$ \\
\hline & motilitas individu & $1,00 \pm 0,00^{c}$ & $1,00 \pm 0,00^{c}$ & $1,00 \pm 0,00^{c}$ & $0,00 \pm 0,00^{d}$ & $0,00 \pm 0,00^{d}$ \\
\hline \multirow[t]{2}{*}{8 hari (W4) } & motilitas massa & $0,00 \pm 0,00^{f}$ & $0,00 \pm 0,00^{f}$ & $0,00 \pm 0,00^{f}$ & $0,00 \pm 0,00^{f}$ & $0,00 \pm 0,00^{f}$ \\
\hline & motilitas individu & $0,00 \pm 0,00^{d}$ & $0,00 \pm 0,00^{d}$ & $0,00 \pm 0,00^{d}$ & $0,00 \pm 0,00^{d}$ & $0,00 \pm 0,00^{d}$ \\
\hline interaksi & & & & & & $* *$ \\
\hline
\end{tabular}

Keterangan : Superskrip yang sama pada kolom dan baris yang sama menunjukkan berbeda tidak nyata $(P>0,05)$,

** Berbeda sangat nyata $(\mathrm{P}<0,01), \mathrm{P} 1: 100 \%$ kuning telur, $\mathrm{P} 2$ : $75 \%$ kuning telur dengan $25 \%$ air kelapa, $\mathrm{P} 3: 50 \%$ kuning telur dengan 50\% air kelapa, P4: 25\% kuning telur dengan 75\% air kelapa, P5: 100\% air kelapa.

Hasil penelitian menunjukkan bahwa terdapat interaksi $(P<0,01)$ antara pengencer dengan lama penyimpanan terhadap motilitas massa dan individu sperma. Setelah dilakukan uji lanjut diketahui bahwa skor tertinggi motilitas massa dan individu terdapat pada perlakuan P1, P2, dan P3 dengan penyimpanan selama 2 hari yang berbeda tidak nyata $(P>0,05)$ dengan skor motilitas massa dan individu pada perlakuan P4 dengan lama penyimpanan selama dua hari. Skor motilitas massa terendah terdapat pada semua perlakuan pengencer dengan penyimpanan selama 8 hari, serta pada perlakuan P4 dan P5 dengan penyimpanan selama 6 hari yang berbeda tidak nyata $(P>0,05)$ dengan skor motilitas massa pada perlakuan $\mathrm{P} 1$ dan $\mathrm{P} 3$ dengan penyimpanan selama 6 hari.

Pada motilitas individu, skor terendah terdapat pada semua perlakuan pengencer dengan penyimpanan selama 8 hari, serta skor motilitas individu pada perlakuan P4 dan P5 dengan penyimpanan selama 6 hari, yang berbeda nyata $(P>0,05)$ dengan kombinasi perlakuan lainnya.

Data pada Tabel 3. menunjukkan bahwa motilitas massa dan individu dapat lebih dipertahankan pada perlakuan P2. Hal ini diduga disebabkan karena perbedaan kandungan nutrisi, menurut Afiati dkk. (2003) dan Toelihere (1981) nutrisi yang lengkap serta kandungan kuning telur dapat menunjang motilitas spermatozoa dan melindungi spermatozoa dari efek cold shock selama penyimpanan. Skor motilitas massa dan individu yang terendah terdapat pada perlakuan P5. Hal ini disebabkan karena air kelapa tidak dapat mempertahankan spermatozoa terhadap efek cold shock yang didukung oleh pendapat Affandhy (2003) dan Afiati dkk. (2003) yang menyatakan bahwa air kelapa tidak mengandung nutrisi yang dapat mencegah efek cold shock terhadap spermatozoa, yang diperkuat dengan hasil penelitian Nunes et al. (2004) yang menunjukkan bahwa pengencer air kelapa hanya dapat mempertahankan motilitas sperma kambing selama 48 jam pada penyimpanan $4^{\circ} \mathrm{C}$.

Motilitas spermatozoa terus menurun seiring dengan lamanya waktu penyimpanan semen yang menurut Yani et al. (2001) karena ketersediaan energi semakin terbatas. Hasil penelitian Affandhy (2003) dan Afiati dkk. (2003) menunjukkan bahwa motilitas sperma pada semen sapi Simmental dan peranakan Ongole yang diencerkan dengan kuning telur dan air kelapa bertahan sampai hari ke tiga. 
Data hasil pengamatan persentase spermatozoa hidup semen berdasarkan pengencer dan lama perlakuan dapat diketahui dari Tabel 4.

Tabel 4. Rata-rata persentase spermatozoa hidup

\begin{tabular}{cccccc}
\hline Waktu & \multicolumn{5}{c}{ Pengencer } \\
\cline { 2 - 6 } Penyimpanan & P1 & P2 & P3 & P4 & P5 \\
\hline 2 hari (W1) & $69,65 \pm 0,88^{\mathrm{bc}}$ & $73,76 \pm 2,53^{\mathrm{ab}}$ & $74,24 \pm 0,98^{\mathrm{a}}$ & $67,70 \pm 1,33^{\mathrm{cd}}$ & $56,91 \pm 5,42^{\mathrm{gh}}$ \\
4 hari (W2) & $64,54 \pm 4,53^{\text {def }}$ & $68,14 \pm 0,37^{\mathrm{cd}}$ & $66,69 \pm 1,57^{\mathrm{cd}}$ & $65,00 \pm 3,88^{\text {cde }}$ & $49,31 \pm 0,67^{\mathrm{jkl}}$ \\
6 hari (W3) & $52,84 \pm 0,78^{\mathrm{hij}}$ & $62,85 \pm 1,64^{\mathrm{ef}}$ & $60,71 \pm 4,05^{\mathrm{fg}}$ & $51,83 \pm 2,83^{\mathrm{ijk}}$ & $45,88 \pm 2,48^{\mathrm{mm}}$ \\
8 hari (W4) & $47,57 \pm 0,65^{\mathrm{kl}}$ & $55,53 \pm 0,94^{\mathrm{hi}}$ & $56,70 \pm 3,62^{\mathrm{gh}}$ & $42,50 \pm 3,14^{\mathrm{mn}}$ & $38,43 \pm 1,12^{\mathrm{n}}$ \\
\hline interaksi & & & & & $*$
\end{tabular}

Keterangan : Superskrip yang sama pada kolom dan baris yang sama menunjukkan berbeda tidak nyata $(P>0,05)$,

* Berbeda nyata $(\mathrm{P}<0,05), \mathrm{P} 1:$ : $100 \%$ kuning telur, $\mathrm{P} 2$ : $75 \%$ kuning telur dengan $25 \%$ air kelapa, $\mathrm{P} 3: 50 \%$ kuning telur dengan 50\% air kelapa, P4: 25\% kuning telur dengan 75\% air kelapa, P5: 100\% air kelapa.

Hasil analisis ragam menunjukkan bahwa terdapat interaksi yang nyata $(\mathrm{P}<0,05)$ antara pengencer dengan lama penyimpanan terhadap persentase spermatozoa hidup. Persentase spermatozoa hidup tertinggi terdapat pada P3W1 $(74,24 \pm 0,98)$ yang berbeda tidak nyata $(P>0,05)$ dengan persentase sperma hidup pada P2W1 $(73,76 \pm 2,53)$. Pada perlakuan pengencer $100 \%$ air kelapa (P5) dengan lama penyimpanan 8 hari memiliki persentase sperma hidup terendah yaitu $38,43 \pm 1,12$ yang berbeda tidak nyata $(P>0,05)$ dengan persentase sperma hidup pada perlakuan P4 dengan penyimpanan 8 hari $(42,50 \pm 3,14)$. Perbedaan kandungan pengencer akan menyebabkan perbedaan kandungan nutrisi yang terdapat dalam pengencer, pengencer yang memiliki nutrisi lebih lengkap dapat mempertahankan kehidupan spermatozoa lebih lama.

Tabel 4. menunjukkan bahwa spermatozoa dapat digunakan untuk inseminasi buatan sampai penyimpanan dua hari dengan perlakuan P5, pada perlakuan P1 dan P4 dapat digunakan sampai hari ke enam, bahkan pada perlakuan pengencer $\mathrm{P} 2$ dan P3 semen masih dapat digunakan pada hari ke delapan.

Rata-rata persentase sperma hidup yang disajikan pada Tabel 4. menunjukkan bahwa perlakuan pengencer P2 dan P3 dapat lebih mempertahankan persentase sperma hidup dibandingkan dengan P1, P4 dan P5. Hal ini diduga karena kelengkapan kandungan nutrisi yang berbeda pada setiap pengencer. Spermatozoa hidup pada pengencer $100 \%$ air kelapa (P5) memiliki persentase terendah, hal ini disebabkan karena air kelapa tidak mampu melindungi sperma dari efek cold shock., berkurangnya energi di dalam pengencer, penurunan $\mathrm{pH}$, efek toksik pada seminal plasma, dan tekanan osmotik dari bahan pengencer (Affandhy, 2003; Isnaini, 2002; Garner and Hafez, 2000; Toelihere, 1981).

Data pada Tabel 4. menunjukkan bahwa waktu penyimpanan yang semakin lama menurunkan jumlah sperma hidup pada semua perlakuan. Hasil penelitian Ismaya and Summers (2006) menunjukkan bahwa lama penyimpanan semen mempengaruhi persentase sperma hidup, yang lebih diperkuat dengan penelitian Affandhy (2003) yang menyimpulkan bahwa persentase sperma hidup pada semen yang diencerkan menggunakan kuning telur dengan air kelapa mulai mengalami penurunan sejak 1 hari sampai 7 hari penyimpanan. Menurut Yani et al. (2001), persentase spermatozoa hidup yang masih tinggi pada awal penyimpanan disebabkan oleh masih tersedianya zat energi yang dibutuhkan, larutan penyanggah yang masih stabil, tekanan osmotik yang masih isotonis, dan umur spermatozoa yang masih segar.

Rata-rata persentase abnormalitas spermatozoa semen dapat dillihat pada Tabel 5 di bawah ini. 
Tabel 5. Rata-rata persentase abnormalitas spermatozoa

\begin{tabular}{|c|c|c|c|c|c|}
\hline \multirow{2}{*}{ Waktu Penyimpanan } & \multicolumn{5}{|c|}{ Pengencer } \\
\hline & P1 & P2 & P3 & P4 & P5 \\
\hline 2 hari (W1) & $18,70 \pm 1,07^{\mathrm{fgh}}$ & $16,54 \pm 1,22^{h}$ & $18,43 \pm 2,75^{\mathrm{gh}}$ & $21,58 \pm 1,39$ efg & $22,52 \pm 2,26^{\mathrm{ef}}$ \\
\hline 4 hari (W2) & $23,19 \pm 2,61^{e}$ & $16,93 \pm 1,33^{h}$ & $21,33 \pm 1,23^{\mathrm{efg}}$ & $25,21 \pm 1,25^{\mathrm{de}}$ & $25,37 \pm 1,07 \mathrm{de}$ \\
\hline 6 hari (W3) & $27,69 \pm 0,73^{c d}$ & $18,41 \pm 1,05^{\mathrm{gh}}$ & $23,61 \pm 1,25^{e}$ & $30,47 \pm 0,79^{c}$ & $36,98 \pm 2,69 b$ \\
\hline 8 hari (W4) & $34,53 \pm 4,71^{b}$ & $24,15 \pm 3,00^{\text {de }}$ & $25,04 \pm 0,18^{\mathrm{de}}$ & $36,19 \pm 3,82^{b}$ & $42,02 \pm 2,60^{a}$ \\
\hline interaksi & & & & & $* *$ \\
\hline
\end{tabular}

\section{KESIMPULAN}

Analisis ragam menunjukkan adanya interaksi yang sangat nyata $(P<0,01)$ antara pengencer dengan lama penyimpanan terhadap persentase abnormalitas. Data pada Tabel 4. menunjukkan bahwa angka persentase abnormalitas terendah adalah $16,54 \pm 1,22 \%$ yang terdapat pada perlakuan P2 dengan penyimpanan selama 2 hari yang berbeda tidak nyata $(P>0,05)$ dengan perlakuan $\mathrm{P} 2$ dengan penyimpanan selama 4 hari $(16,93 \pm 1,33 \%)$ dan 6 hari $(18,41 \pm 1,05 \%)$, serta dengan perlakuan P1 dan P3 saat lama penyimpanan 2 hari. Perlakuan pengencer $100 \%$ air kelapa (P5) dengan lama penyimpanan 8 hari mempunyai persentase abnormalitas tertinggi yaitu $42,02 \pm 2,60 \%$ yang berbeda nyata $(P<0,05)$ dengan semua perlakuan.

Hasil penelitian menunjukkan bahwa dari segi abnormalitas spermatozoa, pada perlakuan P4 dan P5 semen sudah tidak dapat digunakan pada hari kedua penyimpanan, semen dapat digunakan sampai pada hari ke dua pada perlakuan P1 dan P3, tetapi pada perlakuan P2 semen dapat digunakan sampai hari keenam. Menurut Ax et al. (2000) dan Kamal et al. (2005) abnormalitas spermatozoa lebih dari $20 \%$ tidak dapat digunakan untuk inseminasi buatan, hal ini diperkuat oleh pendapat Hunter (1995) yang menyatakan abnormalitas yang tinggi akan menurunkan tingkat fertilitas pada inseminasi buatan.

Persentase abnormalitas terendah terdapat pada pengencer $75 \%$ kuning telur dengan $25 \%$ air kelapa. Menurut Kamal et al. (2005) dan Arifiantini dkk. (2005) terjadinya peningkatan abnormalitas spermatozoa disebabkan oleh efek cold shock dan ketidakseimbangan nutrisi

Abnormalitas spermatozoa semakin meningkat seiring dengan lamanya penyimpanan. Toelihere (1981) menyatakan bahwa penambahan waktu penyimpanan menyebabkan derajat keasaman $(\mathrm{pH})$ semen menurun.

Hasil penelitian menunjukkan bahwa pengencer yang dapat mempertahankan kualitas semen $(\mathrm{pH}$ semen, motilitas spermatozoa, persentase sperma hidup, dan persentase abnormalitas spermatozoa) kambing Nubian adalah pengencer $75 \%$ kuning telur dengan 25\% air kelapa dan pengencer $50 \%$ kuning telur dengan $50 \%$ air kelapa.

\section{DAFTAR PUSTAKA}

Affandhy, L. 2003. Pengaruh Penambahan Cholesterol dan Kuning Telur di dalam Bahan Pengencer Tris-Sitrat dan air Kelapa Muda terhadap Kualitas Semen Cair Sapi Potong. hlm. 77-83. Prosiding Seminar Nasional Teknologi Peternakan dan Veteriner, Bogor, 29-30 September 2003

Afiati, B.Tappa, dan Djuarsawidjaja. 2003. Pengaruh Perbandingan Kuning Telur dan Air Kelapa terhadap Daya Tahan Hidup (Viabilitas) Spermatozoa Sapi Hasil Pemisahan. Media Peternakan 26(3):82-87 Anonimous. 2001. Standar Minimal Balai Inseminasi Buatan di Daerah. Pusat Pengembangan Inseminasi Buatan dan Transfer Embrio (Puspitnak), Lembang.

Anonimous. 2002. Diktat Pelatihan Petugas Desentralisasi Balai Inseminasi Buatan (Bull Master dan Laboran). Balai Inseminasi Buatan, Lembang

Arifiantini, I., T.L. Yusuf, dan Yanti D. 2005. Kaji Banding Kualitas Semen Beku Sapi Friesian Holstein Menggunakan Pengencer dari Berbagai Balai Inseminasi Buatan di Indonesia. Journal Animal Production 7(3):168-176

Ax, R.L., M.R. Dally, B.A. Didion, R.W. Lenz, C.C. Love, D.D. Varner, B. Hafez, dan M.E. Bellin. 2000. Semen Evaluation. p. 365-375. In Hafez, B and E.S.E. Hafez (eds.) Reproduction in Farm 
Animal. $7^{\text {th }}$ ed. Lippincott 7 Wilkins, Philadelphia

Garner, D.L., dan E.S.E. Hafez. 2000. Spermatozoa and Seminal Plasma. P. 96-109. In Hafez, B and E.S.E. Hafez (eds.) Reproduction in Farm Animal. $7^{\text {th }}$ ed. Lippincott 7 Wilkins, Philadelphia

Hafez, B. 2000. Technique for Determining Spermatozoa Concentration Using a Haemocytometer. P. 481-495. In Hafez, B and E.S.E. Hafez (eds.) Reproduction in Farm Animal. $7^{\text {th }}$ ed. Lippincott 7 Wilkins, Philadelphia

Haenlein, Cassese, dan Smith. 2007. Artificial Insemination. http://www.goatworld.com. 4 April 2007

Hunter, RHF. 1995. Fisiologi dan Teknologi Reproduksi Hewan Betina Domestik. Penerbit ITB, Bandung

Ismaya dan Summer. 2006. The Effect of Incubation Time on the Motility, Velocity and Morphological Characteristics of Merino Rams Spermatozoa as Assessed by Computer-Aided Semen Analyzer. J.Indon.Trop.Anim.Agric 31(4)

Isnaini, N. 2002. Pengaruh Lama Simpan terhadap Kualitas Semen Ayam Arab dalam Pengencer Ringer's-Sari Buah Pisang pada suhu $4^{\circ} \mathrm{C}$ Habitat 8(4):258-268

Jiabi, Zegao, dan Taiyong. 2001. Extention of Artificial Insemination in Boer Goats. http://www.igagoatworld.org/publication/proc eeding/abst ract14.pdf. 4 Oktober 2007

Junianto, L., B. Setiono, dan S. Kismiati. 2002. Pengaruh Pengenceran Semen dengan Berbagai Kuning Telur terhadap Motilitas dan Daya Hidup Sperma Ayam Kampung. Jurnal Pengembangan Peternakan Tropis. 27(1):30-35

Kamal, A. Gubartallah, A. Ahmed, Amel, Bakhiet, dan A. Babiker. 2005. Comparative Studies on Reproductive Performance of Nubian and Saanen Bucks under the Climatic Conditions of Khaortum. Journal of Animal and Veterinary Advances 4 (11):942-944

Nunes, J.F., Ferreira, Campos, Monteiro, Pinheiro, Araujo, dan Figuereide. 2004. Viability of Washed and Unwashed Goat Sperm Diluted in Coconut Water, Cooled and Storage at $4^{\circ} \mathrm{C}$. Revista Brasileira de Ciencia Veterinaria 11(3):178-182

Oyeyemi, M.O., M.O. Akusu, dan O.E. Ola-Davies. 2001. Effect of Successive Ejaculation on the Spermiogram of West African Dwarf Goats. http://www.isrvma.org/article/56_4_7.htm. 26 Agustus 2007

Panhwar, F. 2007. Modern Reproductive Methods Used to Enhance Goat Production. http://www.goatworld.com/ModernReproduc
tiveMethodsUsedtoEnhanceGoatProduction. 29 Agustus 2007

Poolperm, P. 2001. Factors Influencing Semen Quality and Fertility in Boars. PhD. Diss. North Carolina State University

Salisbury, GW dan NL Vandemark. 1985. Physiology of Reproduction and Artificial Insemination of Cattle. WH Freeman and Company, United States. Diterjemahkan oleh Djanuar, R. 1985. Fisiologi Reproduksi dan Inseminasi Buatan pada Sapi. Gadjah Mada University Press, Yogyakarta

Steel, R.G.D., and J.H. Torrie. 1980. Principles and Procedures of Statistics. Diterjemahkan oleh Sumantri, B. 1993. Prinsip dan Prosedur Statistika "Suatu Pendekatan Biometrik". PT Gramedia Pustaka Utama, Jakarta

Toelihere, M. 1981. Inseminasi Buatan pada Ternak. Angkasa, Bandung

Wulandari, W. 2007. Lama Hidup Spermatozoa Kambing Peranakan Ettawa pada Beberapa Kadar Glukosa dalam Pengencer Larutan Ringer-Kuning Telur yang Disimpan pada Suhu $5^{\circ} \mathrm{C}$. http://adln.lib.unair.ac.id. 29 Agustus 2007

Yani, A., Nuryadi, dan T. Pratiwi. 2001. Pengaruh Tingkat Substitusi Santan Kelapa pada Pengencer Tris dan Waktu Penyimpanan terhadap Kualitas Semen Kambing Peranakan Ettawah (PE). Jurnal Biosain 1(1):23-29

Yuliyanti, F. 2001. Pengaruh Berbagai Media Pengencer terhadap Kualitas Semen Kalkun Lokal. Skripsi. Fakultas Pertanian. Universitas Lampung, Lampung (tidak dipublikasikan) 